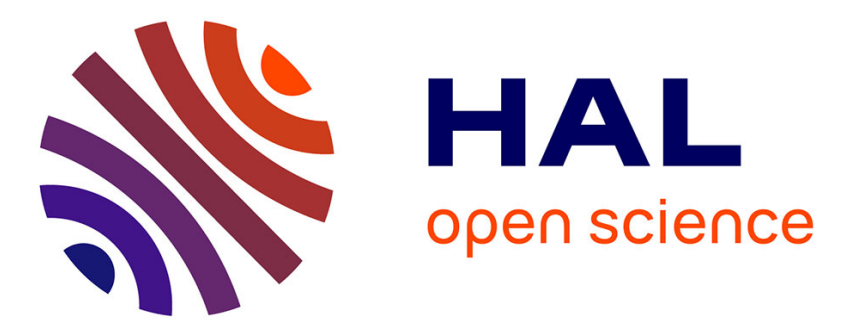

\title{
The three partners of language planning and the revitalization of the Basque language in the Northern Basque Country
}

Jean-Baptiste Coyos

\section{- To cite this version:}

Jean-Baptiste Coyos. The three partners of language planning and the revitalization of the Basque language in the Northern Basque Country. Sociolinguistic Studies, 2013, 7.1 \& 7.2, pp.133-149. artxibo-00922715

\section{HAL Id: artxibo-00922715 https://artxiker.ccsd.cnrs.fr/artxibo-00922715}

Submitted on 30 Dec 2013

HAL is a multi-disciplinary open access archive for the deposit and dissemination of scientific research documents, whether they are published or not. The documents may come from teaching and research institutions in France or abroad, or from public or private research centers.
L'archive ouverte pluridisciplinaire HAL, est destinée au dépôt et à la diffusion de documents scientifiques de niveau recherche, publiés ou non, émanant des établissements d'enseignement et de recherche français ou étrangers, des laboratoires publics ou privés. 


\title{
The three partners of language planning and the revitalization of the Basque language in the Northern Basque Country
}

Jean-Baptiste Coyos

\begin{abstract}
This paper deals with the current situation of the Basque language and the policy implemented in its favor in the Northern Basque Country or French Basque Country. One of the aims is to show the limits of the public linguistic policy implemented, for the first time, by the authorities. If the commitment of the associations of support for the language is important, that of society as a whole is less, even if the latter becomes gradually more favorable. From a general point of view, we can say that three partners or protagonists are involved in the process of recovery or loss of a language. In one way or another, the government and regional and local authorities are the decision-makers and financial backers, the agents of the linguistic policy are the providers, project managers, society and citizens are the addressees/beneficiaries. This leads me to develop a theory of the actors in the process of revitalization or loss of a language, the Three Partners Model, as a descriptive and explanatory framework.
\end{abstract}

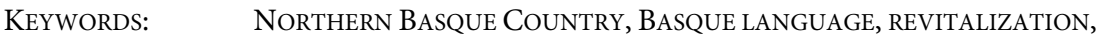
THE THREE PARTNERS MODEL

\footnotetext{
Affiliation

University of Bordeaux 3 and University of Pau, France email: jean-baptiste.coyos@wanadoo.fr
} 


\section{Introduction: the three partners of language planning and the Basque language in the Northern Basque Country}

This paper deals with the current situation of the Basque language (euskara) and the policy implemented in its favor in the Northern Basque Country or French Basque Country. For a good understanding of the complexity of this situation, the different language policies applied in the three Basque administrative units in the Spanish and French states are taken into account.

One of the aims is to show the limits of the public linguistic policy implemented, for the first time, by the authorities (first stage in 2000, second in $2006^{1}$ ). If the commitment of the associations of support for the language is important, that of the society as a whole is less, even if the latter becomes gradually more favorable.

From a general point of view, we can say that three partners - three protagonists - are involved in the process of recovery or loss of a language. I would say that in one way or another government, regional and local authorities are the decision-makers and financial backers, the agents of the linguistic policy are the providers and project managers and society and citizens are the addressees/beneficiaries. This leads me to develop a theory of the actors in the process of revitalization or loss of a language, the Three Partners Model, as a descriptive and explanatory framework. ${ }^{2}$ The need to increase synergy between the three actors appears obvious, since the participation of each is essential to the success of the process of recovery of a minority language. One can even say that the participation of each is essential. This is an indispensable condition of the success of the policy of revitalization of a minority language.

The reflections presented here are focused on the language emancipation (LE) concept as expounded in the introduction text by Anna-Riitta Lindgren. In this way, we can say that the process in progress in the Northern Basque Country's bilingual context improves the position of Basque, which nonetheless remains underprivileged.

In parallel with this theoretical reflection, I wish to propose a point of view about the language policy recently initiated towards the revitalization of the Basque language in the Northern Basque Country, which is a part of the French department called the Pyrénées-Atlantiques. I will try to avoid repetitions of the recent publications about the situation of Basque (Fishman, 1991b; Azurmendi, Bachoc and Zabaleta, 2001; Azurmendi and Martinez de Luna, 2005a, 2005b), and those about the language policy more especially pursued in this part of the Basque Country (Coyos, 2004, 2006, 2009, 2010; Legarra and Bachoc, 2005). ${ }^{3}$ However, to introduce my article, I shall begin with giving some data about it. 


\section{An insight into the situation of Basque in the Northern Basque Country}

The Basque language, euskara, is a non Indo-European language that predates the arrival of those classified as Indo-European in Europe. Basque is isolated, from a genealogical viewpoint, and is unrelated to European languages from a typological viewpoint. The Basque Country, Euskal Herria, is located along the Atlantic Ocean, and is divided between the French and the Spanish states, on both sides of the Pyrenees, with two autonomous communities in the latter state: the Basque Autonomous Community (BAC) and Navarrese Autonomous Community (NAC). In these two communities - but mainly in the BAC - Basque language speakers have gained partial control in a range of private and national institutions. However the advance is very limited in the Northern Basque Country. The Basque Country has a little more than three million inhabitants.

Two languages coexist in the Northern Basque Country (NBC) or French Basque Country. One, official and all-powerful, is present in all areas of use: the French language. The other, the Basque language, is non-official and more and more excluded from the areas in which it has traditionally been present, that is to say the family, the immediate community and social areas such as religion.

Basque is a minority, threatened language in the $\mathrm{NBC}$ and the Basque people make up an historical minority. The vitality of the Basque-speaking community is rather weak in the NBC, compared with other Basque communities.

Thanks to the four sociolinguistic surveys made since 1991, we now have a diachronic perspective of the situation in the entire Basque Country. Full bilinguals have increased from $21.39 \%$ in $1991(505,200)$ to $25.7 \%(665,700)$ in 2006; passive bilinguals have increased from $7.71 \%$ in $1991(182,700)$ to $15.4 \%$ $(397,900)$ in 2006. Much progress has been made in the BAC due to an active institutional language policy, whereas little progress has been made in the NAC.

Since 1991 the situation is one of ongoing retirement in the NBC. Full bilinguals reduced in number from $32.73 \%(66,200)$ to $22.5 \%(51,800)$ in 2006 ; nevertheless, passive bilinguals increased from $7.04 \%(14,700)$ in 1991 to $8.60 \%$ $(19,800)$ in 2006. The unilingual French speakers are now $68.90 \%$, which represents about 158,600 people. One third of all bilinguals are over 65 years of age (Basque Autonomic Government, 2008:81).

The rapid growth of the population in the NBC is mainly due to continuing immigration from other areas of France. French speakers, therefore, are greater in number in NBC, and all Basque-speakers are bilingual. There are no longer any unilingual Basque people. 
All the specialists agree with the fact that, in order to guarantee the future of a language, the fundamental step of inter-generational transmission through families must be taken (sixth stage in the Fishman's Reversing Language Shift model; Fishman, 1991a:398-399; 2001:467). I quote the last sociolinguistic survey:

In the Basque Autonomous Community and Navarre, more than $98 \%$ of children whose parents are bilingual learn Basque at home. Although the corresponding proportion for the North is also high, it stands at ten percentage points lower than in the other regions (...). When one parent doesn't speak Basque, $20 \%$ of children in the BAC, $9.1 \%$ of Navarrese and $4.6 \%$ of northern children still learn Basque at home. (Basque Autonomic Government, 2008:211)

So we can say that the transfer of the mother tongue by Basque-speaking parents is weak in the NBC.

We cannot say that language loss is reversing, or at least stabilizing in this part of the Basque Country, even if, for the first time in 2006, the decrease in the number of full bilinguals has stopped for inhabitants from 16 to 24 years of age, and their numbers have begun to rise. This decrease is due to the development of Basque school teaching.

A second kind of survey, the measurement of street use, repeated every four or five years since 1989, gives us a lot of real data gathered in the field (Soziolinguistika Klusterra, 2007). Here again, the improvement in use in the BAC and among children is salient; on the contrary an inexorable decline is going on in the NBC, even among young speakers.

\section{The actors of revitalization or loss of a language: the Three Partners Model}

From a general point of view, we can say that three protagonists are involved in the process of recovery or loss of a language. I quote Porcher and Faro-Hanoun: 'The three main poles of a linguistic policy are the backer, the provider and the beneficiary' (2000:151). These three partners are essential.

To make it simpler, I would say that the government, the regional and local authorities are the decision-makers and financial backers (le commanditaire), the agents of the linguistic policy are the providers and project managers (le prestataire) and society and citizens are the addressees/beneficiaries (le destinataire). They all interact together.

The most difficult partner to mobilize is civil society (Coyos, 2004:209). Figure 1 below represents the relations between the partners and their respective roles and functions. In the following paragraphs, this three-component model will be adapted to the peculiar situation of the NBC and to the dynamic interactions between the three partners. 


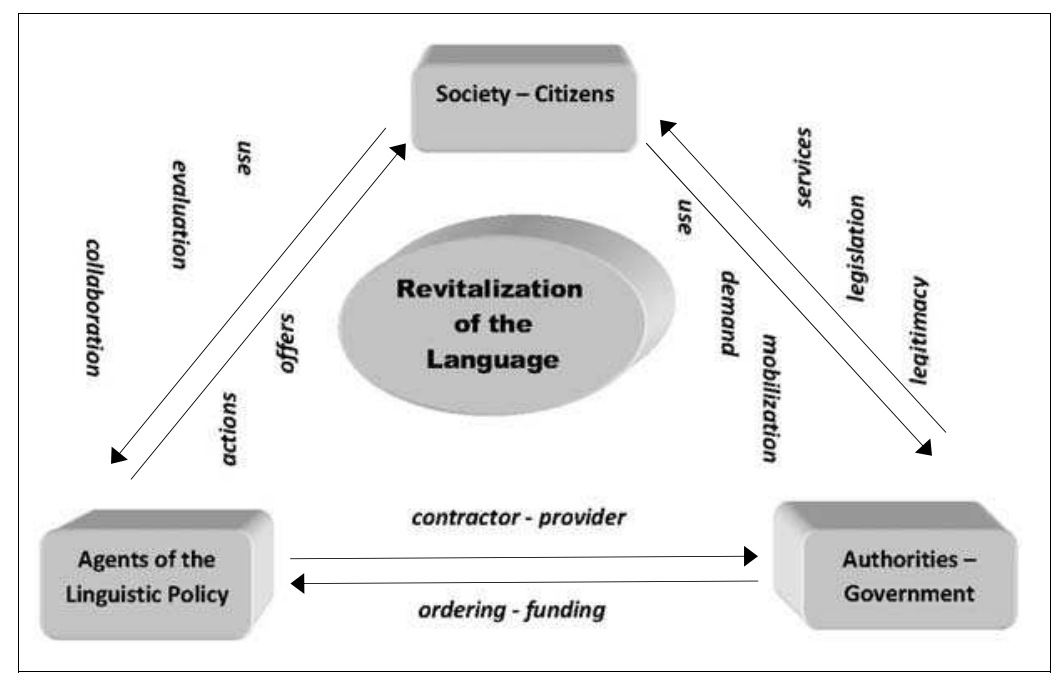

Figure 1: the Three Partners Model

\subsection{The authorities: three main roles}

The institutional support provided by the state or the local government is very important, if not vital. Authorities have at least three main roles: making decisions, funding projects and adopting - or not - language laws and linguistic rights for the language minority.

Sometimes, they are also agents in offering language teaching and its promotion to the educational system and other public services (health, transport, justice, police, and so on). In this way, they lend legitimacy to the revitalization project.

However, institutional policy alone cannot revitalize a threatened language, and active community participation is necessary. The case of the Gaelic language in Ireland is often cited as a language revival movement that failed to resurrect the language. In order to be revived in a modern society, a language must be made relevant for use in a wide variety of functions and domains, including school for example, though not exclusively.

\subsection{The providers: the agents of the linguistic policy}

I have said that the agents of the linguistic policy are the providers and project managers of the implemented language planning. They are sometimes distinct from administrative staff, because public administration and government either don't or did not take this domain into account, or aspects of it.

As we will see in the next section, Basque language activists and Basque language protection associations were for a long time the only providers in the case of Basque in the NBC. In a sense, they had appropriated two roles described 
in the previous paragraph in order to make their projects a reality: making decisions and funding projects. And so, at least in the case of minority languages, language policy makers are not only official, institutional authorities - national, provincial or local - but associations and local groups too, as creator and administrator of immersive schools or minority language radio stations, for instance. In this situation they are agents of the linguistic policy as well as official authorities, sometimes the only one.

\subsection{The beneficiaries: society}

The principal factor necessary to the recovery of a language, the sine qua non, in my opinion and model, is citizen involvement and commitment. The role of citizens belonging to the minority is necessary and sometimes sufficient for the transmission of the language, even if it is a minority language. The most compelling proof, in the case of Basque, is the uninterrupted transmission of the language through centuries, without any public support, and without any school teaching until quite recently.

At the present time, as we know, living conditions have changed for most of the minority language speakers in the world and for speakers of the Basque language, too: in the school system, in mass communications and working environments, etc. Basque cannot exist in the same way as before because the Basque Country is now completely integrated in the European Community; it takes full part in the globalization of pan-Western economy and culture (the 'motor of the language shift', Fishman, 2001:6). Moreover, the responsibility of language planning cannot only be delegated to local authorities, associations and specialists. ${ }^{4}$

Minority language citizens keep the language alive by using and transmitting it. The dominant-language majority helps the revival process of the minority language by learning it and by supporting it. Indeed, we must take into account that, in the case of a linguistic minority, society is two-fold from a linguistic point of view: a dominant-language majority and a bilingual minority. I do not distinguish in this diagram between the various speech communities that form society as a whole.

\section{Language policy makers in the Northern Basque Country: decision-makers, financial backers and providers}

Using this model in the case of the NBC, we will now examine the situation of each partner and its evolution.

The French State is a decision-maker and financial backer (3.1) in the linguistic policy now expanded in the NBC, through two means: through the Ministry of Education, by organizing the teaching of Basque at the primary and secondary 
levels, where it is also a provider (3.2); and through the Public Bureau for the Basque Language, a new public interest organization of linguistic politics, of which it is member (see 4.3 below).

We must first remember the national ideological and legislative context in which language policy makers are working in the NBC: with France's monolingual education and strong assimilationist language policy until recently on one hand, and the non-recognition of any regional or national minority language on the other.

\subsection{The heritage of the old assimilationist policy and French legislation}

The strong assimilationist policy of French official monolingualism during the past two centuries seems to be changing now, particularly under pressure from international opinion and from the European Union, but also due to pressure from French minority language associations.

France is a multilingual state with no provincial language laws, as in Spain. Although ratification of the European Charter for Regional or Minority Languages was blocked in 1999 by the Constitutional Council as contradicting the Fifth Republic's constitutional provision enshrining French as the language of the Republic (article 2), in July 2008 the government proposed a revision of the French Constitution creating a limited official recognition of regional languages as part of the heritage of France (article 75.1). However, this recognition is only declarative.

These languages, therefore, continue to lack any official status. In the same way, the French Republic does not recognize any national minority, such as the Basque minority would be. In a general way, France defends theoretical respect for regional languages and their individual use, but denies the necessary socioeconomic resources and any real public support.

\subsection{Basque language protection associations as providers and language policy makers}

It might be hard to understand why Basque language activists and Basque language protection associations are included in this section among language policy makers. In section 3.2 I gave the beginning of the answer.

Let us take an historical angle. Indeed, it has been a long time since local associations stated that Basque was in a dangerous situation in the NBC. Work had to be done in the 1960s and '70s, opening some areas in the field of language support, such as private immersive schools or Basque-medium schools named ikastolak (the first in France), independent Basque local radio stations, adult 
education, production of pedagogic tools in Basque and so on. ${ }^{5}$ On their own side, public authorities did not do anything in favour of the language, and sometimes stood in the way of the actions of Basque associations.

Bourhis and Landry say: 'Informal support refers to the degree to which a language community has organised itself as a pressure group or organization to represent and safeguard its own language interests in various states and private domains' (2008:187). We can say that there have been some results in this way, particularly with the creation of a public institution in charge of the new linguistic policy named Office public de la langue basque (Public Bureau for the Basque Language, hereafter OPLB). However, associations did not succeed in occupying decision-making roles within this new institution. Nevertheless, some social institutions, such as immersive schools and Basque language radio stations, are governed by their own group, although their development depends on public financial aid.

Basque Language Associations have become operators of the new public policy, carrying on their work but becoming now partners in the linguistic policy: 'The emergence of a new framework set by the linguistic policy project will allow structuring relations in an open way between the Public Bureau for the Basque Language and the association operators. The activities developed by the latter are in a large majority already compatible with the orientations set by the project' (OPLB, 2006:13-14).

\subsection{Language planning in the NBC: public policy under construction}

In this section we will briefly expose the new public policy under construction. The two main pillars are the teaching of Basque and the creation of the OPLB in order to design and manage a public linguistic policy.

As mentioned above, we can say now that the ideological orientations that the French State adopted toward minority languages have changed, partially at least. This is the case with local authorities in the NBC, too. Assimilationist ideology has become weaker and local decision-makers have moved now from laissez-faire to an active linguistic policy.

\subsubsection{Basque language teaching}

The French Ministry of Education organizes the teaching of regional languages such as Basque. In the NBC, there are 25,000 schoolchildren in primary and nursery schools. Among them, 34\% are learning Basque in immersive and in bilingual classes in primary school and 43\% in nursery school (2010-2011 school year). This is the highest percentage among the French regional languages. Over the last ten years, Basque learning has greatly expanded in primary education, 
particularly in bilingual teaching, but very slightly in secondary (students aged 11$14,15 \%$, students aged $15-18,6 \%$ ) and in higher education. The immersive model has expanded to a lesser extent, even if the number of ikastolak and pupils is growing. This model is managed by the private association, Seaska, but since 1994 teacher's salaries have been paid by the Ministry of Education and the syllabi are the same as those used in public education.

We can say that Basque bilingual schools can be seen as a weak model, in the sense of Skutnabb-Kangas (2010) regarding strong vs. weak forms of minority language education. In this kind of school, half of the classes are taught in Basque, and the rest in French. But outside the classroom there are no Basque-speaking personnel. Pupils speak Basque very little and generally not at all, in the classroom or at playtime. On the other hand, Basque immersive schools can be seen as a strong model. All the adults in school speak Basque and the pupils generally always speak Basque one to another, even at playtime.

\subsubsection{The Public Bureau for the Basque Language (Office public de la langue} basque)

In 2004, for the first time, a public interest organisation sponsored by the French state, the Aquitaine Regional Council, the department of Pyrénées Atlantiques, was created: the Office public de la langue basque or Public Bureau for the Basque Language. The Bureau has set up a project of language policy for the promotion and development of the Basque language in years to come that will determine the action of public entities. It focuses on the basic objective of 'complete speakers' and defines children and young people as their top priority (OPLB, 2006:10).

Financial resources for this new policy are still weak: 2 million Euros in 2008. In comparison, the Vice-Ministry for Language Policy of the BAC had a budget of 13 million Euros in 2008 - educational system not included. Fortunately, Basque is a cross-border language and there is also public funding by the BAC - 500,000 Euros to the NBC. If this aid was not accepted by the French authorities until recently, it is now integrated in all public funding of the Bureau's language planning.

In my opinion, the linguistic policy project is too limited, and its final aims are unclear. Priority is given to the teaching of language to children, in order to compensate for very weak family transmission: 'The natural family transmission which has until now insured the vitality of the language does not work now or in a marginal way (...). The development of the teaching of Basque at school has already produced its first effects since the decline of the language seems to be stopped nowadays at the youngest aged classes' (OPLB, 2006:9-10). 
Detailed planning, objectives with figures and schedules are lacking. On the contrary, in the domain of school teaching, the situation is much more satisfactory: there is a real planning. If public linguistic policy does not change, the Basque minority language will be restricted to private and informal use and will not be 'a "language of status" used in public and formal societal contexts' (Bourhis and Landry, 2008:194), except for school teaching. For the moment, the revitalization process is based mainly on individual volition and choice.

In the authorities' minds, the educational system must compensate for weak intergenerational family transmission. The language policy project targets children and youth as a priority, yet little is done to ensure the continuity of the language outside of school and in the Basque speaker's adult life. The OPLB admit it: 'The Public Bureau has not been able to develop a real voluntarist policy to promote the use of Basque, either to public operators or to private ones' (OPLB, 2009a:136).

According to Fishman's Reversing Language Shift model (1991a, 2001), the eight stages are not at all ensured except the eighth and the seventh. ${ }^{7}$ However the second plan after five years of work, the so-called Avant-projet du Cadre Opérationnel 2010-2016, underlines the importance of the use of Basque besides transmission. 'So the Public Bureau offers to make an increase in the interventions in language use domains, while reinforcing action in language transmission domains' (OPLB, 2009b:19). Here there is a change of strategy and the public linguistic policy goes the right way.

\section{The beneficiaries: attitudes and behavior toward the Basque language within society in the Northern Basque Country: contradictory results}

In section 3.3, I have said that the beneficiaries are the third partner, society in the NBC in the case of the Basque language. I stated that citizen involvement and commitment was the sine qua non of success of the transmission of a language, even a minority language, so it is essential to understand the attitude and behavior of these citizens toward the Basque language.

From this perspective, support by French unilingual outgroup and Basque bilingual ingroup citizens who endorse positive attitudes and behaviours towards the Basque minority language is a sine qua non of the revitalization of Basque. They can do this by learning, by using the language, by sending their children to Basque schools, by putting pressure on authorities, etc. By doing these things, they become actors of the revitalization of Basque. 
It is very important to know whether the French unilingual dominant majority in the NBC is sympathetic or not to the existence of the Basque language. In other words, we have to know what the attitude of the society of the NBC is in general regarding the Basque language. Bourhis and Landry say: 'How speakers perceive the vitality of their own language community may be as important as "objective" assessments of group vitality based on census data and measurable institutional support' (2008:191). We will apply this point of view to the Basque language.

Some data follow, and we will see that they are in contradiction. We detail the data from NAC and from the BAC with the aim of making a comparison, and to show the special features of the NBC.

\subsection{Learning the language}

According to the Identité et culture basques au début du XXIème siècle survey, few adults want to learn Basque in the NBC (Baxok et al., 2006). In the NBC 61\% do not want to learn it, compared with $56 \%$ in the NAC and $40 \%$ in the BAC. Those who tried to learn but did not succeed number $8 \%$ in NBC, $15 \%$ in NAC and $28 \%$ in BAC (Baxok et al., 2006:62). Here again, the NBC seems to be less in favour of the language.

Conversely, Basque-language education for children has high approval in the NBC, with 56\% accepting that all children should learn Basque at school and 23\% opposing (Basque Autonomic Government, 2008:130). Most people in the BAC believe that children should be required to learn Basque (82\%), compared to only $43 \%$ in the NAC. It has to be said that the Basque-speaking areas of Navarre only represent about $10 \%$ of the whole.

\subsection{Attitude toward the language}

According to the same most recent sociolinguistic survey, $41.2 \%$ of the NBC population support the promotion of the Basque language, whereas $17.6 \%$ are against it. In the BAC two out of three inhabitants (64.7\%) view action to promote the use of Basque favourably and $11.2 \%$ oppose such an action. In the NAC $37.7 \%$ of people view the action to promote the use of Basque favourably and $34.2 \%$ oppose such an action. Here again the NAC is more opposed.

This brief comparison shows us that the majority of the adult population of the NBC is in favor of Basque-language education for children, and to a lesser extent the promotion of Basque, although they themselves do not want to learn Basque. 


\section{Discussion: the limits of language policy in the Northern Basque Country: toward a synergy between agents of the linguistic policy, authorities and society}

It's time to draw a balance sheet of the situation of the Basque language in the NBC and of the three partners of the process of revitalization in progress. As we have seen throughout this brief and partial report, authorities, Basque language protection associations and society have different roles in linguistic policy respectively as decision-makers and financial backers, providers and beneficiaries. But the case of the NBC shows us that each partner takes on different roles.

If the commitment of the associations of support for the language is important, that of the society as a whole is less, even if it becomes gradually more favorable to Basque revitalization and emancipation. Public linguistic policy is in its infancy. This is a first positive step, with which one cannot be satisfied on its own.

The three protagonists involved in the process of the revitalization of the Basque language are in dynamic interaction. Each component contributes to reinforce or to weaken the implemented policy. How can we encourage society as a whole to become more conscious and mobilized? The objective is to identify the best way of improving the health and vitality of the Basque language, to determine relevant language planning activities to help the Basque language reach a sufficient vitality, given that, as Bourhis and Landry say, 'the quest for total linguistic and cultural security is an illusion today as it always has been throughout History' (2008:206).

"It is important that language use in "solidarity" domains be maintained but also that the group be able to experience and expand its language and culture in “status" domains', say Bourhis and Landry (2008:195). With regard to this prospect, the role of the authorities is very important: the creation of the Public Bureau for the Basque Language is a first step. But the Consultative council which was created at the same time - the council to which representative associations and some qualified people belong - does not have great decision-making power. The Public Bureau for the Basque Language is a governance structure that has to optimize the full collaboration of the three relevant partners - something it does not yet do in my opinion.

I quote Baxok et al., again: 'Institutional control is the dimension of vitality par excellence needed by language-groups to maintain and assert their presence within state and private institutions (...). It is proposed that language groups need to achieve and maintain a favourable position on the institutional control front if they wish to survive as distinctive collective entities within multilingual states' (2006:187). 
On the other side, we have seen that the Basque language is losing speed as a 'language of solidarity'; a language restricted to private and informal use. Here the role of Basque speakers is very important, particularly that of bilingual parents in increasing use in the home environment and among friends and relations. The participation of unilingual French speakers is necessary too, knowing that the current situation is comfortable for them as parents of pupils who learn Basque at school and as a majority who recognize the status and legitimacy of the Basque language, etc.

The absolute necessity for synergy between the three partners of the linguistic policy in favor of Basque appears increasingly obvious, so that the efforts that are made are neither useless nor of little effect. In this way, the development of schooling in Basque brings more and more adult people who are not of Basque origin to become interested in the language. They enroll their children in the Basque school, they listen to Basque music and some of them try to learn the language. At this stage, the Public Bureau for the Basque Language's role in the pursuit of this synergy becomes important, by introducing Basque in local governmental agencies and services, for example, as some town councils are beginning to do. Let us remember that the French state, Aquitaine Regional Council and department of Pyrénées-Atlantiques are the major members of the Bureau. Introducing Basque in local governmental agencies and services would be important progress in the way of public recognition of and emancipation of the language.

\section{Conclusion}

To conclude, I would like to emphasize that the situation and the current politics I have exposed are full of contradictions that are difficult to interpret. The situation of the Basque language in the NBC is complex. However, and fortunately, this situation is not static, and we can say that the 'point of no return' has not been reached in the case of Basque in the NBC. A kind of language emancipation process is beginning. Taking over from the language activists and the Basque language protection associations, the authorities start to develop a concerted policy in the framework of the Public Bureau for the Basque Language. The main difficulty is and will be to persuade the dominant French language majority. There are some advances in this domain.

The 'ambivalence between assimilation and pluralist policy' (Lindgren this volume) seems to be diminishing; the preservation and development of Basque language as public linguistic policy is becoming part of public policy, and it is at its beginning. Cooper says (1989:44): 'It seeks [language planning] to determine who defines the problem to be solved or the behavior to be changed, what interests are at stake, how decisions are reached with respect to goals and means,

\section{equinoxonline}


and the outcomes of implementation, on the one hand, and between each of these and the social context in which planning is embedded, on the other'. I hope the Three Partners Model contributes towards helping to reach this goal, by clarifying the nature of the actors and their roles, their interactions and relationships.

\section{Notes}

1 For the first stage see the Volet 1 Politique linguistique of the Convention spécifique Pays basque 2001-2006 (Etat, Région Aquitaine, Département des Pyrénées-Atlantiques, Conseil des Élus du Pays basque 2000). For the second stage, see the Projet de politique linguistique (OPLB, 2006).

2 Robert L. Cooper says: 'A descriptively adequate account of any given case of language planning ought to tell us, at a minimum, what actors attempted to influence what behaviors, of which people, for what ends, by what means, and with what results' (1989:46-47, italics in original). The Three Partners Model I propose takes into account 'ends', 'means' but first of all 'actors' and 'people', as well as their interactions and relationships.

3 There are many recent works about these two questions written in the Basque language. I do not give them in the bibliography below. Nevertheless I cite Zalbide, 2003 for an example regarding the first question, and Coyos, 2008 and 2009 regarding the second.

4 Cooper considers 'language planning to be 1) the management of innovation, 2) an instance of marketing, 3) a tool in the acquisition and maintenance of power, 4) an instance of decision making' (1989:58). The second and fourth aspects are at the heart of my model; the first one less so. The third is not taken into account.

5 Cooper observes: 'Language planning is sometimes the product of individuals working largely outside the framework of formal organizations; (...) sometimes the product of formal institutions - publishing houses, churches, schools, professional associations, and the like' (1989:88). In the case of the NBC, we can say that it was something intermediate: individuals involved in various small non-professional associations working in different fields and also in cooperation to put pressure on the authorities.

6 In the Bureau's thinking, a 'complete speaker' is someone who is able to speak Basque in all situations of everyday life.

7 Fishman's model consists of an eight-stage process for reviving threatened languages (Fishman, 1991a: 87-109). Efforts should be concentrated on the earlier stages of restoration until they have been consolidated before proceeding to the later stages, from 8 to 1 . In brief:

8. Most of the remaining speakers of the language are elderly and socially isolated from other speakers of the language: acquisition of the language by adults. This is not the case of Basque.

7. Most of the active speakers of the language are socially integrated but beyond child-bearing age. Young people must be encouraged to use the language. 
6. Informal use of the language among people of all age groups and within families where possible. In the NBC there are few localities of this kind, but there are some. This is the crucial stage of intergenerational transmission of the language. It is not ensured in the NBC.

5. In areas in which there is oral competence in the language, encourage literacy in the language. In the NBC a lot of elderly speakers cannot read or write Basque. The French school was the only place where literacy is taught.

4. Encourage the use of the language in compulsory state education. In the NBC, there is no compulsory education in Basque but, as we see above, from one year to the next, schooling in Basque is making progress.

3. Encourage the use of the language in the workplace (lower work sphere). Basque's place is very small with regard to this stage.

2. Encourage the use of the language in local government services and mass media. There are some successful experiments in the media, for instance a network of Basque associative radios with a good audience. But Basque is not getting into local government services.

1. Encourage use of the language in higher education, government etc. There is no political independence in the NBC, so this stage is unattainable.

\section{About the author}

Jean-Baptiste Coyos (1952, Mauléon-Licharre France). Doctor of General Linguistics (Ph.D. in 1998, Paris Descartes University-Sorbonne). Lecturer at the Basque Studies Department of the University of Pau in Bayonne (France). Member of the Basque Text and Language Study Center -UMR 5478 (CNRS, University of Bordeaux 3 and University of Pau) in Bayonne. Member of Euskaltzaindia (Royal Academy of the Basque Language) since 2010. Research interests: Basque language, souletine dialect, minority languages, linguistic policies.

\section{References}

Azurmendi, M.-J., Bachoc, E. and Zabaleta, F. (2001) Reversing language shift: the case of Basque. In J. A. Fishman (ed.) Can threatened languages be saved? 234-259. Clevedon: Multilingual Matters. http://dx.doi.org/10.1515/ijsl.2005.2005.174.1

Azurmendi, M.-J. and Martinez de Luna, I. (2005a) Introduction: presenting the Basque case. International Journal of the Sociology of Language 174: 1-8.

Azurmendi, M.-J. and Martinez de Luna, I. (2005b) Final reflections: Basque: from the present toward the future. International Journal of the Sociology of Language 174: 85105.

Basque Autonomic Government (2008) The continuity of Basque IV: sociolinguistic survey of the Basque Country 2006. Retrieved on 10 October 2011 from <http://www.euskara.euskadi.net/r59-738/en/contenidos/informacion/inkesta_ soziolinguistikoa2006/en_survey/adjuntos/IV_incuesta_en.pdf> 
Baxok, E., Etxegoin, P., Lekunberri, T., Martínez de Luna, I., Mendizabal, L., Ahedo, I., Itzaina, X. and Jimeno, R. (2006) Identité et culture basques au début du XXIème siècle. Donostia/San Sebastián, Basque Country, Spain: Eusko Ikaskuntza.

Bourhis, R. Y. and Landry, R. (2008) Group vitality, cultural autonomy and the wellness of language minorities. In R. Y. Bourhis (ed.) The vitality of the English-speaking communities of Quebec 185-212. Montréal: Universités de Montréal and Moncton.

Cooper, R. L. (1989) Language planning and social change. Cambridge: Cambridge University Press.

Coyos, J.-B. (2004) Politique linguistique Langue basque et langue occitane du Béarn et de Gascogne. San Sebastián/Donostia, Spain: Elkar.

Coyos, J.-B. (2006) L'enseignement peut-il 'sauver' une langue menacée? l'exemple du Pays Basque. Lapurdum X: 19-33. [Bayonne, Centre de Recherche sur la Langue et les Textes Basques IKER - UMR 5478].

Coyos, J.-B. (2008) Hizkuntza-politika Ipar Euskal Herrian: nondik nora? Ibilbidearen azterketa [Linguistic policy in the Northern Basque Country: from where to where? examination of the course]. Bat Soziolinguistika aldizkaria 67: 79-102. [Andoain (Spain): Soziolinguistika Klusterra].

Coyos, J.-B. (2009) Euskara eta legedia Ipar Euskal Herrian: Gizarte elebidun baterantz aukerak eta mugak [Basque language and legislation in the NBC: towards a bilingual society, limits and possibilities]. Bat Soziolinguistika aldizkaria 70: 41-55. [Andoain (Spain): Soziolinguistika Klusterra].

Coyos, J.-B. (2010) État des lieux de l'enseignement scolaire du basque en France. In C. Torreilles and M.-J. Verny (coord.) Enseigner une langue régionale (= Les Langues Modernes 4: 32-37).

Etat, Région Aquitaine, Département des Pyrénées-Atlantiques, Conseil des Élus du Pays basque (2000) Volet 1 Politique linguistique, Convention spécifique Pays Basque 2001-2006: 13-22. Retrieved on 10 October 2011 from <http://www.lurraldea. net/bibliodocs/PB2010/conv-spedec01.pdf>

Fishman, J. A. (1991a) Reversing Language Shift. Theoretical and Empirical Foundations of Assistance to Threatened Languages. Clevedon: Multilingual Matters.

Fishman, J. A. (1991b) The case of Basque and Frisian. In J. A. Fishman, Reversing language shift: theoretical and empirical foundations of assistance to threatened languages 149-186. Clevedon: Multilingual Matters.

Fishman, J. A. (ed.) (2001) Can threatened languages be saved? reversing language shift, revisited: a 21st century perspective. Clevedon: Multilingual Matters.

Legarra, J. and Bachoc, E. (2005) Language policy and planning of the status of Basque, II: Navarre and the Northern Basque Country. International Journal of the Sociology of Language 174: 25-38.

Office public de la langue basque (2006) Projet de politique linguistique 'Un objectif central: des locuteurs complets Un coeur de cible: les jeunes générations'. Retrieved on 10 October 2011 from <www.mintzaira.fr.> 
Office public de la langue basque (2009a) Etat des lieux provisoire de l'action menée par l'Office public de la langue basque 2005-2009. Retrieved on 10 October 2011 from $<$ www.mintzaira.fr.>

Office public de la langue basque (2009b) Avant-projet du Cadre Opérationnel 2010-2016 pour la politique linguistique publique. Retrieved on 10 October 2011 from $<$ www.mintzaira.fr. $>$

Porcher, L. and Faro-Hanoun, V. (2000) Politiques linguistiques. Paris: L'Harmattan.

Skutnabb-Kangas, T. (2010) Education of indigenous and minority children. In J. A. Fishman and O. García (eds) Handbook of language and ethnic identity. Volume I. 186-204. Oxford: Oxford University Press.

Soziolinguistika Klusterra (2007) Kale erabileraren V. neurketa 2006 [Vth Measurement of Street Use 2006]. Emaitzak, Azterketak, Gogoetak [Data, Studies, Observations]. Bat Soziolinguistika aldizkaria 64. [Andoain (Spain): Soziolinguistika Klusterra].

Zalbide, M. (2003) Ahuldutako Hizkuntza Indarberritzea: teoriak zer dio? [Revitalization of weakened language: what does the theory say?] Retrieved on 10 October 2011 from $<$ http://www.erabili.com/zer_berri/muinetik/1056974834> 